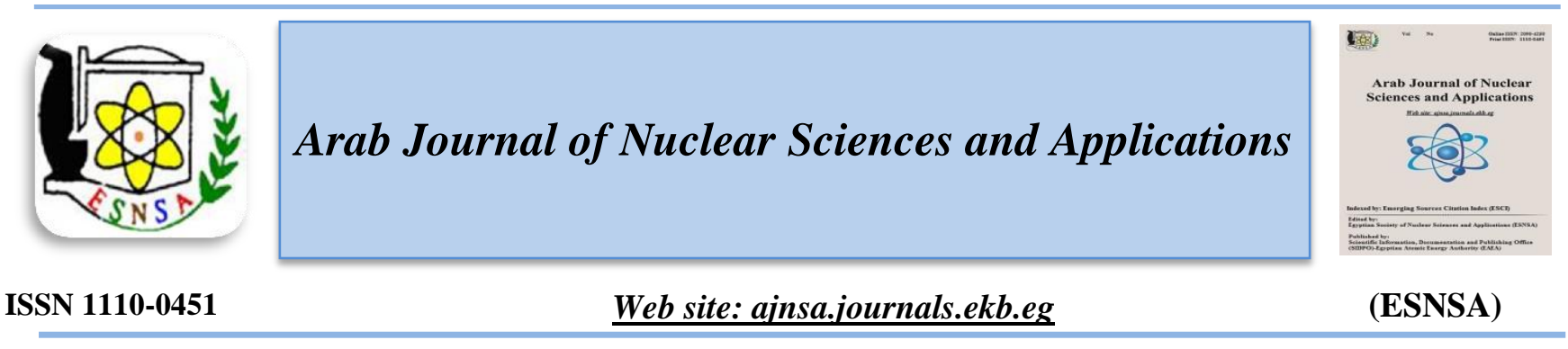

\title{
Assessment of the Background Radiation of Telecommunication Masts in Ebonyi State, Nigeria
}

\author{
Arthur N. Nwachukwu ${ }^{* a}$, Chukwunonso F. Ikeagwuani ${ }^{a}$ and Nkechinyere V. Nwachukwu ${ }^{b}$ \\ ${ }^{a}$ Department of Physics, Alex Ekwueme Federal University, Ndufu-Alike, Nigeria \\ ${ }^{b} 2$ Department of Community Medicine, Alex Ekwueme Federal University Teaching Hospital, Abakaliki, \\ Nigeria
}

Received $5^{\text {th }}$ June 2020 In this study, the background radiation of ten selected mobile phone base stations was monitored to Accepted $10^{\text {th }}$ Jan. 2021 ascertain their radiological risk. The requirement to monitor them is because they are established contributors to background radiation. There is, therefore, often a requirement to monitor them to ascertain if their radiation levels have passed the safety standards. The study was carried out using the Radalert 100 radiation monitor and a Geographical Positioning System (Garmin GPSMAP 765). The mean background radiation exposure rate ranges from $0.0133 \mathrm{mRhr}-1$ to $0.0200 \mathrm{mRhr}-1$. The obtained values are higher than the world standard limit of $0.013 \mathrm{mRhr}-1$ recommended by ICRP. The calculated absorbed dose rates for the various base stations ranged from $115.71 \mathrm{nGh}-1$ to $174.00 \mathrm{nGyh}-1$. These values of absorbed dose rates were observed to be far higher than the world permissible value of 89 nGyh-1. The annual effective dose equivalent (AEDE) for the exposure values ranged from $0.142 \mathrm{mSvy}-1$ to $0.213 \mathrm{mSvy}-1$ which are far lower than the ICRP permissible limits of $1.00 \mathrm{mSvlyr}$ for the public and implies that the base stations do not pose any immediate radiological risks. The excess lifetime cancer risk for the stations' users was all above the $0.29 \times 10-3$ world recommended value and therefore, suggests a possibility of the base station workers developing radiation-related illnesses over a longer time. Regular radiological monitoring of all the base stations in Ebonyi State is recommended.

Keywords: 5G network; Radalert-100; Radiofrequency radiation; Exposure rates; Cancer risk

\section{Introduction}

There has been a growing concern and rage about the ongoing installation of $5 \mathrm{G}$ network in different countries of the world. Social media across the globe, especially in Nigeria, have been agog with the debate on whether $5 \mathrm{G}$ network has more demerits than merits. While a group of thought argued that $5 \mathrm{G}$ network emits a lot of radiation and therefore, not without severe health and safety implications; others believe that it only emits nonionizing radiation in the range of that of $2 \mathrm{G}, 3 \mathrm{G}$, and $4 \mathrm{G}$ networks which are adjudged to produce no known health concern. To allay the anxiety it created in Nigeria, the Nigerian Communications Commission (NCC) in a publication dated 5th of
April 2020, explained that 5G network has no health-related effect [1].

Exposure to network radiation can come from mobile phones or base stations transmission. The individual mobile phone operates by communicating with a fixed installation known as a base station or a telecommunications structure. Since the mobile phone and its base station are a two-way radio, they produce radiofrequency (RF) radiation as a means of communicating and expose the people near them to $\mathrm{RF}$ radiation. The wide use of mobile phones and the continuous erection of base stations have inevitably raised the question of whether there are any implications for human health [2].

Corresponding author: samaz711@yahoo.com

DOI: 10.21608/ajnsa.2021.31879.1362

(C)Scientific Information, Documentation and Publishing Office (SIDPO)-EAEA 
Just like the case of $5 \mathrm{G}$, there have been debates on whether RF radiation from mobile phones and its base stations pose risk to health and these have understandably led to some concern from the members of the public for many decades. Initially, the international scientific community believed that the power from these base station antennas is quite small to cause health hazards, provided people are kept away from direct contact with the antennas [2]. Results of expert studies by World Health Organization (WHO), UK Advisory Group on Non-Ionizing Radiation (AGNIR), and Scientific Committee on Emerging and Newly Identified Health Risks (SCENIHR) all show that there is no evidence of adverse health effects of radiation exposure from base stations, provided it remains below the levels set by current standards [3].

However, quite a lot of recently published results have shown that radiation from mobile phone and the base stations constitute health hazard both to human health and the environment. For example, Singh et al. [4] reported that most laboratory studies have indicated a direct link between exposure to RF radiation and adverse biological effects. Several in vitro studies have reported that RF radiation induces various types of cancer and DNA or chromosomal damage [4].

An assessment of the health hazards of nonionizing radiation from telecommunication mast on the exposed community using a descriptive cross-sectional survey by Akintonwa et al. [5] showed that about $62 \%$ of the people were affected health wise by exposure to mast radiation and that minimizing them will go a long way to improve healthy living.

Technical reports on toxicology and carcinogenesis study in rats exposed to whole-body radiofrequency radiation at $900 \mathrm{MHz}$ and in mice exposed to whole-body radiofrequency radiation at $1,900 \mathrm{MHz}$ revealed that there is clear evidence that $\mathrm{RF}$ radiation is a human carcinogen, causing glioma and vestibular schwannoma (acoustic neuroma) [6]. There is also some evidence of an increased risk of developing thyroid cancer, and clear evidence that RF radiation is a multi site carcinogen [6].

Ferdous [7] reported that $70 \%$ of teenagers who use mobile phones (MPs) in Sylhet city are facing different types of health challenges after assessing MPs usage and awareness of health hazards among the adolescents.
Evidence on the relationship between non-ionizing radiation and increasing the level of radiation exposure was studied by Santini et al. [8]. They found more significant symptoms of health effect within a radius of $300 \mathrm{~m}$ from the mobile phone base stations: irritability, depression, memory loss, dizziness, decreased libido, headache, sleep disorders, malaise $(200 \mathrm{~m})$; and tiredness $(300 \mathrm{~m})$. Similarly, Oberfeld et al. [9] found that persons living close to base stations reported more symptoms of irritability, fatigue, headache, nausea, memory loss, visual disturbances, dizziness, and cardiovascular problems, directly proportional to their exposure to microwaves.

Other research reports which found a direct link of $\mathrm{RF}$ radiation to human and environmental effects include Galeev [10], Kim et al. [11], Klaps et al. [12], Bandara [13], Kucer and Pamukcu [14], Singh [15], Koppel et al. [16], Alnajjar et al. [17], Kazaure et al. [18], Mushroor et al. [19], Abuelsaoud [20], Bhagat et al. [21], Malik et al. [22], Sallam [23], Aitken et al. [24], Pearce [25], Jooyan et al. [26] and Vornoli et al. [27].

This work is in furtherance of the research done on background radiation emanating from base stations $[5,8,10,12,13,15,16,17,18,25]$ in an attempt to establish whether they constitute health effects. Normally, to assess RF radiation risk, the ElectricField Strength $(\mathrm{v} / \mathrm{m})$ at the base stations is measured and then compared with the International Commission on Non-Ionizing Radiation Protection (ICNIRP) standard. However, in this study, the RF radiation was analyzed in terms of radiation indices and compared with International Commission on Radiological Protection (ICRP) standards. The indices determined are:

i. the Background Ionization Radiation (BIR) levels of the base stations

ii. the mean BIR level and the radiation absorbed dose rate (ADR) of the various masts iii. the annual effective dose equivalent (AEDE) of the stations and its environment

iv. and the excess lifetime cancer risk (ELCR) of the study area.

\section{Materials and Methods}

This study was carried out at ten different base stations in Ebonyi State using radiation meter, a Geographical Positioning System (GPS), and a constructed stand of $1 \mathrm{~m}$ above the ground. The radiation meters used in this work for 
measurement of background radiation is the Radalert-100. The choice of this meter was based on its portability; sensitivity and response which are appropriate since the radiation measurement is for low radiation field [28]. The Radalert 100 uses a Geiger-Muller tube to detect $\alpha, \beta, \gamma$, and $\mathrm{x}$-rays. A pulse of electrical current is produced by the Geiger tube any time radiation passes through it and results in ionization which the CPU registers as counts and is displayed on the screen. The Radalert 100 displays the counts in the mode you choose: counts per minute (CPM), mili roentgen per hour $(\mathrm{mR} / \mathrm{hr})$, or total counts for a timed period. However, counts per second (CPS) and micro Sieverts per hour $(\mu \mathrm{Sv} / \mathrm{hr})$ are the used SI units. The procedure for calibration is as reported in the monitors' operating manual [29]. Measurements from the Radalert-100 monitor were acquired in units of $\mathrm{mR} / \mathrm{hr}$.

The method of radiation measurement employed in this work is the direct observation and measurement of radiation levels from the Base stations studied with the above-mentioned detector. The detector was held one meter above the ground surface at each of the base stations and readings were taken. Each reading was repeated ten times at four-minute intervals to account for any error due to fluctuation in the environment parameters [30]. For each of the selected base stations, the mean Background Ionizing Radiation (BIR) reading of each set of ten measurements was obtained and denoted as mean BIR exposure rates for each point. The mean BIR exposure rates obtained were quantitatively used to assess the radiation health impact to workers within the immediate environment of the stations by performing several radiological health indices calculations such as absorbed dose rate, annual effective dose equivalent and excess lifetime cancer risk using the necessary relations given by Rafique et al [30] and Ezekiel [31].

The radiation absorbed dose rates were evaluated using equation (1).

$$
1 \mu \mathrm{R} / \mathrm{h}=8.7 \eta \mathrm{Gy} / \mathrm{h}
$$

The computed absorbed dose rates were used to calculate the annual effective dose equivalent (AEDE) using equation (2).

$$
\operatorname{AEDE}=\operatorname{ADR}(\eta \mathrm{Gy} / \mathrm{h}) \times 8760 \mathrm{~h} \times 0.7 \mathrm{~Sv} / \mathrm{Gy} \times 0.2
$$

ADR equals the absorbed dose rate in $\eta \mathrm{Gy} / \mathrm{h}, 8760$ equals the total hours in a year, $0.7 \mathrm{~Sv} / \mathrm{Gy}$ equals the dose conversion factor from absorbed dose in the air to the effective dose using an occupancy factor of 0.2 for outdoor exposure as recommended by UNSCEAR.

The excess lifetime cancer risks were evaluated using the annual effective dose values by employing equation (3)

\section{$\mathrm{ELCR}=\mathrm{AEDE}(\mathrm{mSv} / \mathrm{y}) \times \mathrm{DL} \times \mathrm{RF} \quad$ (3)}

Where AEDE is the annual effective dose equivalent, DL is the average duration of life (70 years) and RF is the fatal cancer risk factor per sievert $\left(\mathrm{Sv}^{-1}\right)$. For low-dose background radiation, which is considered to produce stochastic effects, ICRP 103 uses a fatal cancer risk factor value of 0.05 for public exposure [32].

The location of each base station was measured with the aid of a global positioning system (GPS). GPS is a space-based satellite navigation system that provides location and time information in all weather conditions, anywhere on or near the earth. It is maintained by the United States Government and is freely accessible to anyone with a GPS receiver.

\section{Results and Discussion}

The results of the BIR exposure level measurements and the associated radiological health parameters for the studied telecommunication masts are given in tables 1 and 2 respectively, while in Figure 1, the measured background ionizing radiations (BIRs) in the Base stations were compared with recommended ICRP limits.

The BIR levels of the Base stations range from 0.008 to $0.028 \mathrm{mR} / \mathrm{h}$ with a total mean value which ranges from $0.0133 \mathrm{mR} / \mathrm{h}$ to $0.0200 \mathrm{mR} / \mathrm{h}$ (Table 1). The BIR of mast 1 ranges from $0.010 \mathrm{mR} / \mathrm{h}$ to $0.020 \mathrm{mR} / \mathrm{h}$ with a mean value of $0.0148 \mathrm{mR} / \mathrm{h}$. Masts 2 and 6 both have minimum and maximum values of $0.010 \mathrm{mR} / \mathrm{h}$ and $0.022 \mathrm{mR} / \mathrm{h}$ respectively but with different mean BIR values of 0.0167 and 0.0158 respectively. Masts 3, 4, 5, 7, 8, 9 and 10 have BIR values which range from $0.160-0.027$ $\mathrm{mR} / \mathrm{h}, \quad 0.012-0.028 \mathrm{mR} / \mathrm{h}, \quad 0.008-0.023 \mathrm{mR} / \mathrm{h}$, $0.013-0.023 \mathrm{mR} / \mathrm{h}, 0.008-0.017 \mathrm{mR} / \mathrm{h}, 0.013-0.024$ $\mathrm{mR} / \mathrm{h}$, and $0.011-0.024 \mathrm{mR} / \mathrm{h}$ respectively. They have mean values of $0.020,0.0188,0.0142$, $0.0176, \quad 0.0133, \quad 0.0169$, and $0.0153 \mathrm{mR} / \mathrm{h}$ respectively.

Masts 3 and 8 have the highest and the lowest mean values of BIR respectively. The radiation level of mast 3 is dangerous given its closeness to Girls' Hostel of Alex Ekwueme Federal University 
(FUNAI). As can be observed in Fig. 1, all the points exceeded the $0.013 \mathrm{mR} / \mathrm{h}$ recommended ambient BIR exposure level [32]. The variations in BIR can be majorly attributed to the RF radiation from the base stations. The high values of BIR can further be attributed to the presence of fuel stations and excavation sites around the Base stations. It can also be due to the different geological and geophysical characterization of the environments [33].
The radiation health indices (which include the mean absorbed doses, annual effective dose equivalent, and the excess lifetime cancer risk) associated with BIR of the masts are as shown in Table 2. The mean absorbed dose of BIR exposure is $142.158 \mathrm{nGy} / \mathrm{h}$ while the mean annual effective dose equivalent of the stations is $0.1744 \mathrm{mSv} / \mathrm{y}$. Both the mean and specific absorbed doses of the base stations are far higher than the recommended safe limit of $84.0 \mathrm{nGy} / \mathrm{h}$ [34-35].

Table 1. Result of background ionizing radiation of the different telecommunication masts.

\begin{tabular}{|c|c|c|c|c|c|c|c|c|c|c|}
\hline S/N & Mast 1 & Mast 2 & Mast 3 & Mast 4 & Mast 5 & Mast 6 & Mast 7 & Mast 8 & Mast 9 & Mast 10 \\
\hline $\mathbf{1}$ & 0.015 & 0.01 & 0.016 & 0.02 & 0.015 & 0.012 & 0.021 & 0.015 & 0.018 & 0.012 \\
$\mathbf{2}$ & 0.018 & 0.012 & 0.019 & 0.022 & 0.023 & 0.01 & 0.02 & 0.017 & 0.013 & 0.015 \\
$\mathbf{3}$ & 0.013 & 0.018 & 0.027 & 0.015 & 0.012 & 0.02 & 0.016 & 0.013 & 0.014 & 0.011 \\
$\mathbf{4}$ & 0.011 & 0.018 & 0.022 & 0.016 & 0.008 & 0.02 & 0.02 & 0.009 & 0.024 & 0.021 \\
$\mathbf{5}$ & 0.015 & 0.022 & 0.021 & 0.028 & 0.014 & 0.014 & 0.017 & 0.012 & 0.023 & 0.024 \\
$\mathbf{6}$ & 0.015 & 0.018 & 0.02 & 0.021 & 0.012 & 0.018 & 0.017 & 0.015 & 0.013 & 0.014 \\
$\mathbf{7}$ & 0.013 & 0.017 & 0.023 & 0.017 & 0.014 & 0.012 & 0.013 & 0.017 & 0.018 & 0.016 \\
$\mathbf{8}$ & 0.02 & 0.018 & 0.017 & 0.02 & 0.013 & 0.022 & 0.023 & 0.013 & 0.013 & 0.012 \\
$\mathbf{9}$ & 0.01 & 0.02 & 0.016 & 0.012 & 0.019 & 0.014 & 0.014 & 0.008 & 0.016 & 0.015 \\
$\mathbf{1 0}$ & $\mathbf{0 . 0 1 8}$ & $\mathbf{0 . 0 1 4}$ & $\mathbf{0 . 0 1 9}$ & $\mathbf{0 . 0 1 7}$ & $\mathbf{0 . 0 1 2}$ & 0.016 & 0.015 & 0.014 & 0.017 & 0.013 \\
Mean & $\mathbf{0 . 0 1 4 8}$ & $\mathbf{0 . 0 1 6 7}$ & $\mathbf{0 . 0 2 0}$ & $\mathbf{0 . 0 1 8 8}$ & $\mathbf{0 . 0 1 4 2}$ & $\mathbf{0 . 0 1 5 8}$ & $\mathbf{0 . 0 1 7 6}$ & $\mathbf{0 . 0 1 3 3}$ & $\mathbf{0 . 0 1 6 9}$ & $\mathbf{0 . 0 1 5 3}$ \\
\hline
\end{tabular}

Table 2. Radiation health indices associated with BIR of various telecommunication masts.

\begin{tabular}{|c|c|c|c|c|c|c|}
\hline \multirow[b]{2}{*}{ Masts } & \multirow[b]{2}{*}{ Location Name } & \multirow[b]{2}{*}{ Geographical Location } & \multirow[b]{2}{*}{$\begin{array}{c}\text { Mean } \\
\text { BIR }\end{array}$} & \multicolumn{3}{|c|}{ Radiation health indices } \\
\hline & & & & $\begin{array}{c}\text { Absorbed } \\
\text { dose } \\
\text { (nGy/h) }\end{array}$ & $\begin{array}{c}\text { Annual effective } \\
\text { dose } \\
\text { equivalent (mSv/y) }\end{array}$ & $\begin{array}{c}\text { Excess lifetime } \\
\text { cancer risk } \\
\times 10^{-3}\end{array}$ \\
\hline 1 & COLLEGE, JUNCTION & N06으'57.4" E00809'50.2" & 0.0148 & 128.76 & 0.158 & 0.553 \\
\hline 2 & ZENITH BANK, FUNAI & N06 $08^{\prime} 03.4^{\prime \prime} E 008^{\circ} 08^{\prime} 35.9^{\prime \prime}$ & 0.0167 & 145.29 & 0.178 & 0.623 \\
\hline 3 & GIRLS HOSTEL, FUNAI & N06 $07^{\prime} 42.5^{\prime \prime} \mathrm{E} 008^{\circ} 08^{\prime} 41.2^{\prime \prime}$ & 0.02 & 174.00 & 0.213 & 0.746 \\
\hline 4 & GEOSCIENCE LAB, FUNAI & N06이'30.1" E00808'38.4" & 0.0188 & 163.56 & 0.201 & 0.704 \\
\hline 5 & A1 COMPLEX, FUNAI JUNCTION & N06 $06^{\prime} 41.0^{\prime \prime}$ E008 $09^{\prime} 38.2^{\prime \prime}$ & 0.0142 & 123.54 & 0.152 & 0.532 \\
\hline 6 & HOTEL, FUNAI JUNCTION & N06 $06^{\prime} 48.5^{\prime \prime}$ E008 $09^{\prime} 47.3^{\prime \prime}$ & 0.0158 & 137.46 & 0.169 & 0.592 \\
\hline 7 & NWAKPU MARKET & N0609'25.3" E00808'29.9" & 0.0176 & 153.12 & 0.188 & 0.658 \\
\hline 8 & AZUIYOKU RD, ABAKALIKI 1 & N06¹8'208" E00805'704" & 0.0133 & 115.71 & 0.142 & 0.497 \\
\hline 9 & AZUIYOKU RD, ABAKALIKI 2 & N06 ${ }^{\circ} 18^{\prime} 20.2^{\prime \prime} \mathrm{E}^{\prime} 008^{\circ} 05^{\prime} 46.0^{\prime \prime}$ & 0.0169 & 147.03 & 0.180 & 0.630 \\
\hline 10 & BEHINDVEGAS ABAKALIKI & 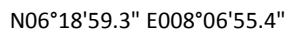 & 0.0153 & 133.11 & 0.163 & 0.571 \\
\hline Mean & & & 0.01634 & 142.158 & 0.1744 & 0.6106 \\
\hline
\end{tabular}




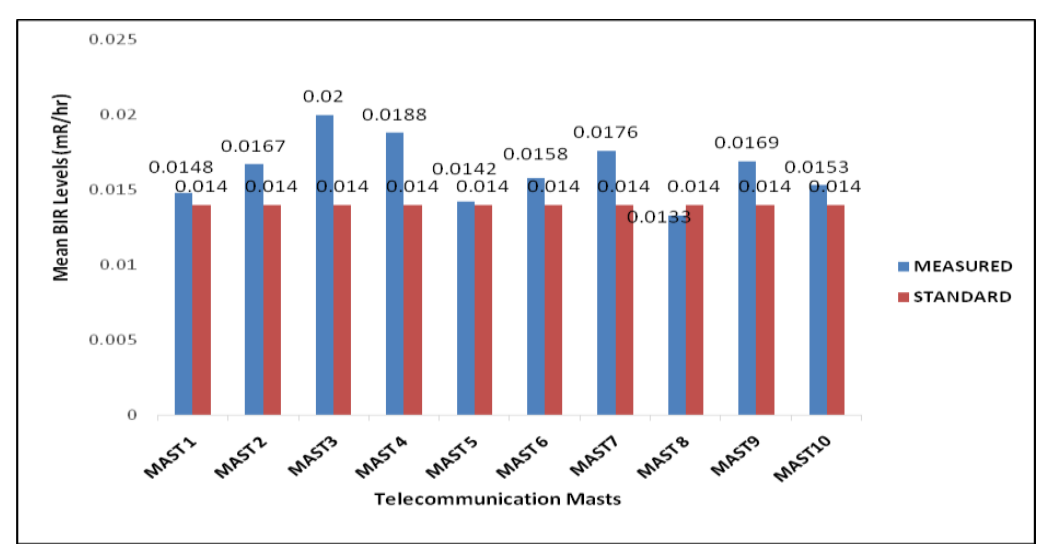

Fig.1. Comparison of BIRS of the masts with recommended ICRP limit.

The annual effective dose is a radiation protection index that quantifies the whole-body absorbed dose per year [33]. The values for the annual effective dose for all the masts in this study are lower than the ICRP permissible limits of 1.00 $\mathrm{mSv} / \mathrm{yr}$ for the general public [32]. This indicates that the studied masts are in good agreement with the permissible limit. The absorbed dose rates arising from the BIR levels of the masts and the annual effective radiation doses at these rates do not constitute any immediate radiological health effect on the mast workers and the general public.

The values for the cancer risks obtained in this work are far higher than the average value of $0.29 \times 10-3$ as recommended by UNSCEAR [34, 36]. The implication of this is that workers who visit the base stations on daily basis and members of the public who either live or work few meters away from the stations and end up spending long hours within the stations are likely to develop cancer at ages of 65 to 70 years or above of their lifetime. It is therefore recommended that the radiation levels of the masts and hence surroundings be monitored against any further increase.

\section{Conclusions}

The background radiation measurements of all the different base stations were found to be higher than the ICRP recommended values. This can be attributed majorly to RF radiation released from the masts. Other possible reasons are the presence of diesel power generating sets, the geological formations, and geographical settings of the area. Although the mean absorbed dose rate of BIR exposure of each of the masks is higher than the set limit, it does not constitute any immediate radiological risk. This is supported by the calculated values for the annual effective dose of the masts which are all lower than the ICRP permissible limits. The calculated excess lifetime cancer risk values are all far above the recommended average value - which implies that people who live or work close to the base stations and end who spend long time there have the potential of developing cancer from the ages of 65 years and above. Although, the studied base stations do not constitute immediate risk both to human health and the environment; the result shows they certainly do on the long run. Therefore, it is recommended that regular radiological monitoring be encouraged, and the data considered as a radiological baseline for telecommunication masts in Ebonyi State. This should be extended to the unmonitored base stations especially those located within public facilities and residential areas like the ones studied in this work. The 10-meter setback of base stations from domicile buildings should be strictly followed as our observation shows that it is not always the case.

\section{Acknowledgment}

The authors gratefully acknowledge AVR Green Albatross Solutions Ltd - an environmental consultancy firm, for sponsoring this research.

\section{References}

1. Nigerian Communications Commission. (2020) NCC Clears doubt over 5G, COVID-19 and Security; Abuja

2. Kwan-Hoong, N. (2003) Raditaion, Mobile Phones, Base Stations and Your Health, Malaysian Communications and Multimedia Commission, pp. 10.

3. Hardell, L. (2017) World Health Organization, radiofrequency radiation and health. 
International Journal of Oncology, 51:405-413. https://doi.org/10.3892/ijo.2017.4046

4. Singh, R., Nath, R., Mathur, A.K. et al. (2018) Effect of radiofrequency on reproductive health. Indian Journal of Medical Research 148:92-99. doi: 10.4103/ijmr.IJMR_1056_18

5. Akintonwa, A., Busari, A.A., Awodele, O. et al. (2009) The hazards of non-ionizing radiation of telecommunication mast in an urban area of Lagos, Nigeria. African Journal of Biomedical Research 12(1):3135.https://www.ajol.info/index.php/ajbr/article/ view/95129

6. Hardell, L. and Carlberg, M. (2019) Comments on US National toxicology program technical reports on toxicology and carcinogenesis study in rats exposed to whole-body radiofrequency radiation at $900 \mathrm{MHz}$ and in mice exposed to whole-body radiofrequency radiation at 1,900MHz. International Journal of Oncology, 54

https://doi.org/10.3892/ijo.2018.4606

(1):111-127.

7. Ferdous, J. (2017) Mobile phone usage and awareness of health hazards among the adolescents in Sylhet city. Imperial Journal of Interdisciplinary Research 3(11):325-330. https://pdfs.semanticscholar.org/0352/4e07af9 6a475259f888aac45740819af34f7.pdf

8. Santini, R., Santini, P., Danze, J.M. et al. (2002) Survey on the health of residents of mobile telephone relay stations: II. Effects of the age of the subjects, the duration of their exposure and their position in relation to antennas and other electromagnetic sources. Pathol Biol (Paris), 51: 412-5.

9. Oberfeld, G., Navarro, A.E., Portoles, M. et al. (2010) The microwave syndrome: further aspects of a Spanish study. http://www.mindfully.org/Technology/2004/M icrowave-Syndrome Oberfeld1may04.htm (acessado em 08/Abr/2010).

10. Galeev, A.L. (2000) The effects of microwave radiation from mobile telephones on humans and animals. Neuroscience and Behavioural Physiology https://doi.org/10.1007/BF02463157.

11. Kim, K.H., Kabir, E. and Jahan, S.A. (2016) The use of cell phone and insight into its potential human health. Environmental Monitoring \& Assessment 188, 221. https://doi.org/10.1007/s10661-016-5227-1

12. Klaps, A., Ponocny, I., Winker, R. et al. (2016) Mobile phone base stations and well-being - A meta-analysis. Science of the Total environment, 544:2430.https://doi.org/10.1016/j.scitotenv.2015.11. 009

13. Bandara, P. (2016) Mobile phone use and the brain cancer incidence rate in Australia. Cancer Epidemiology, 44:110-111. https://doi.org/10.1016/j.canep.2016.08.006.

14. Kucer, N. and Pamukcu, T. (2014) Selfreported symptoms associated with exposure to electromagnetic fields: a questionnaire study. Electromagnetic Biology \& Medicine, 33(1):15-17. https://doi.org/10.3109/15368378.2013.783847

15. Singh, K., Nagaraj, A., Yousuf, A. et al. (2016) Effect of electromagnetic radiations from mobile phone base stations on general health and salivary function. Journal of International Society of Preventive \& Community Dentistry, 6(1):54-59. https://doi.org/10.4103/22310762.175413

16. Koppel, T., Ahonen, M., Carlberg, M. et al. (2019) Radiofrequency radiation from nearby mobile phone base stations: a case comparison of one low and one high exposure apartment. Oncology Letters, 18:5383-5391. https://doi.org/10.3892/ol.2019.10899

17. Alnajjar, H., Alnaser, N.W. and Alnaser, W.E. (2019) Level of electromagnetic radiation emitted from mobile phone base station during F1 race in Kingdom of Bahrain. International Journal of Physics: Study \& Research, 2(1):6570. doi: 10.18689/ijpsr-1000109

18. Kazaure, J.S., Danladi, T.A., Ibrahim, J. et al. (2016) Study on electromagnetic field emission from GSM base stations in Nigeria. IOSR Journal of Electronics \& Communication Engineering 11(6):83-88.doi:10.9790/28341106048388

19. Mushroor, S., Hague, S. and. Amir, R.A. (2020) The impact of smart phones and mobile devices on human health and life. International Journal of Community Medicine \& Public Health 7(1):9-15. http://dx.doi.org/10.18203/23946040.ijcmph20195825

20. Abu-Elsaoud, A.M. (2015) Effect of microwave electromagnetic radiofrequency on germination and seedling growth consequencies of six wheat Triticum aestivum L. Cultivars. Advances in Environmental Biology 9(24): 270-280. http://www.aensiweb.net/AENSIWEB/aeb/aeb /2015/November/270-280.pdf

21. Bhagat, S., Varshney, S., Bist, S.S. et al. (2016) Effects on auditory function of chronic exposure to electromagnetic field from mobile phones. Ear, Nose \& Throat Journal 95(8):1822.

https://www.ncbi.nlm.nih.gov/pubmed/275518 48

22. Malik, S., Pati, A.K. and Parganiha, A. (2019) Short- and long-duration to cell phone

Arab J. Nucl. Sci. \&Applic. Vol. 54, No. 1 (2021) 
radiofrequency waves produce dichotomous effects on phototactic response circadian characteristics of locomotor activity rhythm in zebrafish , Danio rerio. Biological Rhythm Research.

https://doi.org/10.1080/09291016.2019.166594 2

23. Sallam, A.E., Hassan, S.A., Hassaneen, E. et al. (2016) Environmental stress of mobile phone EM radiation on locomotor activity and melatonin circadian rhythm of rats. Biological Rhythm Research, 47(4):597-607. https://doi.org/10.1080/09291016.2016.117336 1

24. Houston, B.J., Nixon, B., King, B.V. et al. (2016). The effect of radiofrequency electromagnetic radiation on sperm function. Reproduction, 152(6): 263-276. doi: 10.1530/REP-16-0126.

25. Pearce, J.M. (2020) Limiting liability with positioning to minimize negative health effects of cellular phone towers. Environmental Research 181, 108845. https://doi.org/10.1016/j.envres.2019.108845

26. Jooyan, N., Goliaei, B., Bigdeli, B. et al. (2019) Direct and indirect effects of exposure to $900 \mathrm{MHz}$ GSM radiofrequency electromagnetic fields on $\mathrm{CHO}$ cell line: Evidence of bystander effect by non-ionizing radiation. Environmental Research, 174:176187.

https://doi.org/10.1016/j.envres.2019.03.063

27. Vornoli, A., Falcioni, L., Mandrioli, D. et al. (2019) The contribution of In vivo mammalian studies to the knowledge of adverse effects of radiofrequency radiation on human health. Int $\mathbf{J}$ Environ Res Public Health,16:(18):3379.https://doi.org/10.3390/ije rph16183379.

28. Agbalagba, O.E., Avwiri G.O. and Ononugbo, C.P. (2016) GIS mapping of impact of industrial activities on the terrestrial background ionizing radiation levels in Ugheli metropolis and environs, Nigeria. Environmental Earth Sciences, 75:(21):1425.https://doi.org/10.1007/s12665016-. 6216-y

29. International Medcom, Radalert 100 Nuclear Radiation Monitor Operating Manual, 6871 Abbott Ave. Sebastopol, CA (2013) 1.

30. Rafique, M., Rahman, S.U., Basharat, M. et al. (2014). Evaluation of excess lifetime cancer risk from gamma dose rates in Jhelum valley. Journal of Radiation Research and Applied Sciences 7(1):29-35 https://doi.org/10.1016/j.jrras.2013.11.005

31. Ezekiel, A.O. (2017) Assessment of excess lifetime cancer risk from gamma radiation levels in Efurum and Warri cities of Delta State, Nigeria. Journal of Taibah University for science, $11:(3) 367-380$. https://doi.org/10.1016/j.jtusci.2016.03.007

32. Paquet, F., Bailey, M.R., Leggett, R.W. et al. (2019).Occupational Intakes of Radionuclides: Part 4. ICRP Publication 141, Ann. ICRP 48(23):9-501. doi: 10.1177/0146645319834139

33. Ugbede, F.O. (2018) Measurement of background ionizing radiation exposure levels in selected farms in communities of Ishielu LGA, Ebonyi State. Journal of Applied Sciences and Environmental Management, 22(9):1427-1432.

DOI: 10.4314/jasem.v22i9.11

34. UNSCEAR, (2018), Sources, Effects and Risks of Ionizing Radiation, UNSCEAR 2017 Report, United Nations, New York. pp 1.

35. Ononugbo C.P. and Mgbemere, C.J. (2016) Dose rate and annual effective dose assessment of terrestrial gamma radiation in Notre fertilizer plant, Onne, Rivers State, Nigeria. International Journal of Emerging Research in Management and Technology, 5(9):30-35.

36. Audu, M.U., Avwiri, G.O. and Ononugbo, C.P. (2019) Evaluation of background ionizing radiation level of selected oil spill communities of Delta State, Nigeria. Current Journal of Applied Science and Technology, 38(3):1-9. https://doi.org/10.9734/cjast/2019/v38i330362. 